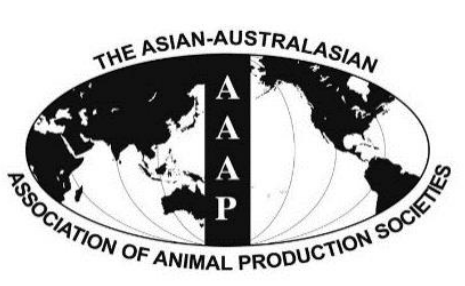

Open Access

Asian Australas. J. Anim. Sci.

Vol. 29, No. 9 : 1229-1238 September 2016

http://dx.doi.org/10.5713/ajas.16.0158

www.ajas.info

pISSN 1011-2367 elSSN 1976-5517

\title{
Relationships between Single Nucleotide Polymorphism Markers and Meat Quality Traits of Duroc Breeding Stocks in Korea
}

\author{
J. S. Choi ${ }^{1,2}$, S. K. Jin' ${ }^{2}$, Y. H. Jeong ${ }^{3}$, Y. C. Jung ${ }^{4}$, J. H. Jung ${ }^{4}$, K. S. Shim ${ }^{5}$, and Y. I. Choi ${ }^{1, *}$ \\ ${ }^{1}$ Department of Animal Science, Chungbuk National University, Cheongju 361-763, Korea
}

\begin{abstract}
This study was conducted to determine the relationships of five intragenic single nucleotide polymorphism (SNP) markers (protein kinase adenosine monophosphate-activated $\gamma 3$ subunit [PRKAG3], fatty acid synthase [FASN], calpastatin [CAST], high mobility group AT-hook 1 [HMGA1], and melanocortin-4 receptor [MC4R]) and meat quality traits of Duroc breeding stocks in Korea. A total of 200 purebred Duroc gilts from 8 sires and 40 dams at 4 pig breeding farms from 2010 to 2011 reaching market weight $(110 \mathrm{~kg})$ were slaughtered and their carcasses were chilled overnight. Longissimus dorsi muscles were removed from the carcass after 24 $\mathrm{h}$ of slaughter and used to determine pork properties including carcass weight, backfat thickness, moisture, intramuscular fat, $\mathrm{pH}_{24 \mathrm{~h}}$, shear force, redness, texture, and fatty acid composition. The PRKAG3, FASN, CAST, and MC4R gene SNPs were significantly associated with the meat quality traits $(\mathrm{p}<0.003)$. The meats of PRKAG3 (A 0.024/G 0.976) AA genotype had higher $\mathrm{pH}$, redness and texture than those from PRKAG3 GG genotype. Meats of FASN (C 0.301/A 0.699) AA genotype had higher backfat thickness, texture, stearic acid, oleic acid and polyunsaturated fatty acid than FASN CC genotype. While the carcasses of CAST (A 0.373/G 0.627) AA genotype had thicker backfat, and lower shear force, palmitoleic acid and oleic acid content, they had higher stearic acid content than those from the CAST GG genotype. The MC4R (G 0.208/A 0.792) AA genotype were involved in increasing backfat thickness, carcass weight, moisture and saturated fatty acid content, and decreasing unsaturated fatty acid content in Duroc meat. These results indicated that the five SNP markers tested can be a help to select Duroc breed to improve carcass and meat quality properties in crossbred pigs. (Key Words: Duroc, Single Nucleotide Polymorphism Markers, Carcass Trait, Meat Quality, Fatty Acid Composition)
\end{abstract}

\section{INTRODUCTION}

Duroc boar is used as a terminal sire at commercial pig production. This breed has an excellent growth rate and higher intramuscular fat content than other breeds (Suzuki et al., 2003). Pig breeders are at the top of the pyramid structure of swine industry and play a vital role in the

\footnotetext{
* Corresponding Author: Y. I. Choi. Tel: +82-43-261-2550, Fax: +82-43-273-2240, E-mail: yangilchoi@ chungbuk.ac.kr

2 Department of Animal Resources Technology and Swine Science \& Technology Center, Gyeongnam National University of Science and Technology, Jinju 660-758, Korea.

${ }^{3}$ Hanwoo Department, Korea Animal Improvement Association, Seoul 137-871, Korea.

${ }^{4}$ Jung P\&C Institute, Yongin 446-982, Korea.

5 Department of Animal Biotechnology, Chunbuk National University, Jeonju 561-756, Korea.

Submitted Feb. 29, 2016; Revised Jun. 9, 2016; Accepted Aug. 10, 2016
}

introgression of superior genes to the commercial pigs. Thus, the ability of breeding stock related to economic traits is the most important factor that influences the success or failure of swine industry (Ibáñez-Escriche et al., 2014).

Due to the advances in genetic technology, new livestock sectors such as breeder management, traceability systems, transgenic animal technology, and livestock disease control, which helped improving the meat quality, have been evolved (Dalvit et al., 2007; Jang et al., 2012). Over the past several decades, breeding strategies have been directed to improve carcass traits, meat quality traits, growth rate, and reproductive performance of commercial animals. Of the pork properties, meat quality traits such as color, tenderness, marbling, and juiciness mostly influence the purchase decision of consumers in the market. So, extensive researches were conducted to improve meat quality. Furthermore, many researchers have studied to identify the genes associated with various economic traits in

Copyright $@ 2016$ by Asian-Australasian Journal of Animal Sciences This is an open-access article distributed under the terms of the Creative Commons Attribution Non-Commercial License (http://creativecommons.org/licenses/by-nc/3.0/), which permits unrestricted non-commercial use, distribution, and reproduction in any medium, provided the original work is properly cited. 
livestock (Mignon-Grasteau et al., 2005).

The protein kinase adenosine monophosphate-activated $\gamma 3$ subunit (PRKAG3), an $R N$ gene, has a significant impact on processed yield and meat quality as the gene regulates glycogen content in muscle (Milan et al., 2000). Ciobanu et al. (2001) found the PRKAG3 allele in several pig breeds, including Landrace, Large White, Berkshire, Duroc, and Duroc synthetics.

The fatty acid synthase $(F A S N)$ gene is located on pig chromosome 12, and has significant effects on the fatty acid composition of pork (Clop et al., 2003). The pig FASN gene which is associated with fatty acid composition of backfat is located in the quantitative trait locus (QTL) region 0 to 40 $\mathrm{cM}$, and is reported to affect the gadoleic acid (C20:1, a mono-unsaturated fatty acid) content in backfat (Muñoz et al., 2007).

The calpastatin (CAST) which has been found in all the tissues that contain calpains, is a specific inhibitor of calpain enzymes (Lonergan et al., 2010). Ciobanu et al. (2004) found that two associated CAST genes (Arg249Lys and Ser638Arg) located on the swine chromosome 2 region were related to the tenderness of longissimus dorsi (LD) muscle in pigs. The endogenous calpain system plays a major role in postmortem muscle proteolysis and meat tenderization processes (Lonergan et al., 2010). The high mobility group AT-hook 1 (HMGAl) gene which is related to the obesity of humans has been mapped at the peak of the fat deposition QTL on pig chromosome 7 (Kim et al., 2004). The HMGAl polymorphisms are consistently associated with fat deposition traits across several pig populations, except for a pure Duroc in which the distribution of a specific $H M G A 1$ genotypic class was relatively small (Kim et al., 2004).

Growth performance and carcass characteristics are very important in the pig industry, and the melanocortin-4 receptor $(M C 4 R)$, a Rhodopsin-like $\mathrm{G}$ protein-coupled receptor, is primarily expressed in nerve systems and plays an important role in the regulation of food intake, energy balance, and body weight in mammals (Adan et al., 2006).

Therefore, the objective of this study was to determine the relationships between the five single nucleotide polymorphism (SNP) markers (PRKAG3, FASN, CAST, $H M G A 1$, and $M C 4 R$ ) and carcass traits as well as the quality traits of Duroc meat.

\section{MATERIALS AND METHODS}

\section{Animals, carcass grading, and carcass measurements}

A total of 200 purebred Duroc gilts were used in this study. Duroc pigs were a part of the pig improvement network program in Korea (Korea Animal Improvement Association, KAIA), and raised in four farms from 2010 to 2011. In the each farm, 50 gilts of progenies from 2 sires and 10 dams were allotted to five pens as 10 pigs. Pigs raised on feeds were based on the Korean Feeding Standard for Swine (National Institute of Animal Science, 2012). After pigs per pen reached the market weight of $110 \mathrm{~kg}$ on average, they were slaughtered following the guidelines of Livestock Products Sanitary Control Act (Ministry of Food and Drug Safety in Korea, 2010), and then chilled overnight in a $4^{\circ} \mathrm{C}$ cold room. At $24 \mathrm{~h}$ postmortem, carcass traits including carcass grading, backfat thickness, and carcass length were measured by the personnel from the Animal Products Grading Services, Korea. Then, the LD muscle from the left side of carcass between 5th and 13th rib was collected and analyzed in the respective laboratories for meat quality and genomic DNA information at Chungbuk National University, Korea.

\section{Genomic DNA analysis}

Genomic DNA was extracted from $300 \mathrm{~g}$ of tissue samples according to a standard protocol (DNeasy Blood \& Tissue Kit, Qiagen, Hilden, Germany). A total of five candidate gene (PRKAG3, FASN, CAST, HMGA1, and $M C 4 R$ ) polymorphisms were previously reported and detailed information about these SNPs and their respective polymerase chain reaction (PCR)-restriction fragment length polymorphism (RFLP) genotyping approaches is illustrated in Table 1. The PCRs were performed in a $10-\mu \mathrm{L}$ PCR buffer $(10 \mathrm{mM}$ Tris- $\mathrm{HCl}, 50 \mathrm{mM} \mathrm{KCl}$, and $0.1 \%$ TritonX-100) containing $12 \mathrm{ng}$ of genomic DNA, $1.5 \mathrm{mM}$ $\mathrm{MgCl}_{2}, 10 \mathrm{pmol}$ of each primer, $200 \mu \mathrm{M}$ of each $\mathrm{dNTP}$, and 2.5 units of Taq DNA polymerase (Solgent, Daejeon, Korea). The thermocycling reaction was performed in a PTC-200 thermocycler (MJ Research, Watertown, MA, USA) with a $10 \mathrm{~min}$ initial denaturation at $95^{\circ} \mathrm{C}$. A total of 40 cycles of $\mathrm{PCR}$ reactions were carried under the following thermocycling conditions: $95^{\circ} \mathrm{C}$ for $30 \mathrm{~s}, 45^{\circ} \mathrm{C}$ to $65^{\circ} \mathrm{C}$ for $30 \mathrm{~s}$ and $72^{\circ} \mathrm{C}$ for $40 \mathrm{~s}$. The final extension was done at $72^{\circ} \mathrm{C}$ for $5 \mathrm{~min}$. The result of the PCR reaction was identified by $2 \%$ agarose gel electrophoresis at $100 \mathrm{mV}$ for $20 \mathrm{~min}$. The information for each primer sequence, annealing temperature, and fragment size is given in Table 1. All restriction enzymes were purchased from New England BioLabs (Ipswich, MA, USA), and restriction digests were performed according to the manufacturer's recommendations. Digested PCR products were analyzed on a $2.5 \%$ to $4 \%$ agarose gel, and each allele was scored manually. The restriction enzymes and the polymorphic fragments used for SNP genotyping are given in Table 1.

\section{Physico-chemical analysis of carcass}

pH of meat: The $\mathrm{pH}$ was measured in triplicate using a digital pH meter (8603, Metrohm, Herisau, Swiss). About $10 \mathrm{~g}$ of the sample was cut into small pieces to which 90 $\mathrm{mL}$ of distilled water was added, and a slurry was made 
Table 1. PCR primers and restriction enzymes used for SNP genotyping of five candidate genes

\begin{tabular}{|c|c|c|c|c|c|c|}
\hline Genes & $\begin{array}{l}\text { Primer sequences } \\
\left(5^{\prime} \rightarrow 3^{\prime}\right)\end{array}$ & $\begin{array}{l}\text { Fragment } \\
\text { size (bp) }\end{array}$ & $\begin{array}{l}\mathrm{T}_{\mathrm{A}} \\
\left({ }^{\circ} \mathrm{C}\right)\end{array}$ & $\begin{array}{c}\text { Restriction } \\
\text { enzyme }\end{array}$ & $\begin{array}{l}\text { Size of the allelic } \\
\text { polymorphism (bp) }\end{array}$ & Reference \\
\hline PRKAG3 & $\begin{array}{l}\text { GGAGCAAATGTGCAGACAAG } \\
\text { CCCACAAGCTCGCTTCTT }\end{array}$ & 258 & 37 & FokI & 197,61 & Ciobanu et al. (2001) \\
\hline FASN & $\begin{array}{l}\text { GGGCCTGGACTCGCTCAT } \\
\text { ACGGTGATGGAGCCCTCGAT }\end{array}$ & 312 & 37 & BssSI & 161,151 & Kim et al. (2011) \\
\hline$C A S T$ & $\begin{array}{l}\text { TTCCCTTCATCTCTAAGTCA } \\
\text { ATGCACAATCGGACTTC }\end{array}$ & 237 & 37 & Hру188I & 137,47 & Ciobanu et al. (2004) \\
\hline$H M G A 1$ & $\begin{array}{l}\text { AGAAGGAGCCCAGCGAAGT } \\
\text { ACAGTGCTCACCCAATGGC }\end{array}$ & 723 & 37 & NaeI & 596,127 & Kim et al. (2006) \\
\hline$M C 4 R$ & $\begin{array}{l}\text { TACCCTGACCATCTTGATTG } \\
\text { ATAGCAACAGATGATCTCTTTG }\end{array}$ & 226 & 62 & TaqI & 156,70 & Kim et al. (2000) \\
\hline
\end{tabular}

PCR, polymerase chain reaction; SNP, single nucleotide polymorphism; PRKAG3, Protein kinase adenosine monophosphate-activated $\gamma 3$ subunit, FASN, fatty acid synthase; CAST, calpastatin; HMGA1, high mobility group AT-hook 1; MC4R, melanocortin-4 receptor.

using a homogenizer (T25B, IKA Sdn, Bhd., Rawang, Malaysia). The $\mathrm{pH}$ meter was calibrated daily with standard buffers of $\mathrm{pH} 4.0$ (9863 pH buffer solution, Mettler Toledo, Schwerzenbach, Swiss) and 7.0 (9865 pH buffer solution, Mettler Toledo, Swiss) at $25^{\circ} \mathrm{C}$.

Moisture and lipid: Moisture and lipid were assayed according to the AOAC methods (1995).

Shear force: Slice of LD muscle, weighing approximately $100 \pm 5 \mathrm{~g}$, was placed was placed into polypropylene bag and then cooked for $40 \mathrm{~min}$ at $70^{\circ} \mathrm{C}$ in the water-bath, and subsequently cooled for $30 \mathrm{~min}$. Samples were cut into $1 \times 2 \times 1 \mathrm{~cm}$ (width $\times$ length $\times$ height) pieces. The maximum weight were measured by a shearing test using a Rheo meter (Model Compac-100, SUN SCIENTIFIC Co., Tokyo, Japan) under the following operational conditions: Table speed of $110 \mathrm{~mm} / \mathrm{min}$, Graph interval of $20 \mathrm{msec}$ and Load cell (max) of $10 \mathrm{~kg}$ using the RDS (Rheology Data System, Tokyo, Japan) Ver 2.01.

Color of meat: The Commission Internationale de l'Eclairage redness $\left(\mathrm{a}^{*}\right)$ of sausage was measured using a Minolta colorimeter (CR-400, Konica Minolta, Tokyo, Japan). The instrument was standardized using a whiteplate $(\mathrm{Y}=93.5, \mathrm{x}=0.3132, \mathrm{y}=0.3198)$ and D65 illuminant source before the measurements. The color variables were measured at five points on the central part of the cut surface of the slices of the samples. The thickness of samples were between 12 and $15 \mathrm{~mm}$ so that they did not absorb the light reflected from the bottom.

Texture: A total of five well trained in-house tasting panelist evaluated subjective characteristics of texture using a 5-point scale, score 1 through 5 (extremely undesirable to highly desirable). The sample were evaluated independently by the panelists in three different times.

Fatty acids: Total lipids of samples were extracted by using chloroform-methanol $(2: 1, \mathrm{v} / \mathrm{v})$ according to the procedure of Folch et al. (1957). An aliquot of the total lipid extract was methylated as described by Morrison and Smith
(1964). Fatty acid methyl esters were analyzed using a gas chromatograph (Varian 3800, Agilent Technology, Palo Alto, CA, USA) fitted with a fused silica capillary column, Omegawax $205 \quad(30 \mathrm{~m} \times 0.32 \mathrm{~mm}$ I.D., $0.25-\mu \mathrm{m}$ film thickness). The injection port was at $250^{\circ} \mathrm{C}$ and the detector was maintained at $300^{\circ} \mathrm{C}$. Results were expressed as percentages based on the total peak area.

Statistical analysis: The genotypes of the five candidate genes (PRKAG3, FASN, CAST, HMGA1, and MC4R) obtained from the testing materials were classified, and their frequencies were calculated. To determine possible effects of SNP genotypes on traits, the chi-square statistic was used for significant different test among means. Genotypic effects of variations in the five candidate genes were estimated with mixed-model analysis using the PROC MIXED of SAS 9.3 software package (SAS, 2003). The model used in the statistical analysis are as follow:

$$
\mathrm{Y}_{\mathrm{ijklm}}=\mu+\mathrm{G}_{\mathrm{i}}+\mathrm{F}_{\mathrm{j}}+\mathrm{D}_{\mathrm{k}}+\mathrm{P}_{\mathrm{l}}+\mathrm{A}_{\mathrm{m}}+\mathrm{e}_{\mathrm{ijklm}},
$$

where $Y_{i j k l m}$ is the observed value of phenotype traits, $\mu$ is the mean of the samples, $G_{i}$ is the fixed effect of genotype, $F_{j}$ is the covariate effect of farms, $D_{k}$ is the covariate effect of slaughter date, $\mathrm{P}_{1}$ is the polygenic effect of Duroc lines, $A_{m}$ is the covariate effect of age and $e_{i j k l m}$ is the random error.

\section{RESULTS AND DISCUSSION}

\section{Analysis of SNP marker genotypes}

Table 2 shows genotype and allele frequency analyses of five polymorphisms in the candidate genes of the Duroc breeding stock. The genotype counts of the PRKAG3 were 4, 81, and 114 for AA, AG, GG genotypes, respectively. The frequency of the A allele was 0.224 and $G$ allele was 0.776 . In the FASN gene, the genotype counts were 19, 85, and 100 for CC, CA, AA genotypes, respectively. The frequency of 
Table 2. Allele and genotype freuquencies of studied polymorphism of the candidate genes in Duroc breeding stock

\begin{tabular}{lccccc}
\hline Item & PRKAG3 & FASN & CAST & HMGAl & MC4R \\
\hline Allele frequency & & & & & \\
Allel 1 (Minor) & $\mathrm{A}(0.23)$ & $\mathrm{C}(0.30)$ & $\mathrm{A}(0.37)$ & $\mathrm{T}(0.30)$ & $\mathrm{G}(0.21)$ \\
Allele 2 (Major) & $\mathrm{G}(0.67)$ & $\mathrm{A}(0.70)$ & $\mathrm{G}(0.63)$ & $\mathrm{C}(0.70)$ & $\mathrm{A}(0.79)$ \\
Genotype count (Head) & AA:4 & CC:19 & AA:31 & TT:8 & GG:11 \\
& AG:81 & CA:85 & AG:90 & TC:100 & GA:59 \\
& GG:114 & AA:100 & GG:83 & CC:88 & AA:125 \\
\hline
\end{tabular}

${ }^{1}$ No of total genotypes for PRKAG3 (protein kinase adenosine monophosphate-activated $\gamma 3$ subunit), FASN (fatty acid synthase), CAST (Calpastatin), HMGA1 (high mobility group AT-hook 1), and MC4R (melanocortin-4 receptor) were 199, 204, 204, 196, and 195, respectively.

the $\mathrm{C}$ allele was 0.301 and A allele was 0.669. All the observed counts of the genotype at the CAST gene were 31 , 90, and 83 for AA, AG, GG genotypes, respectively. The frequency of the A allele was 0.373 and $\mathrm{G}$ allele was 0.627 . The genotype frequencies of the HMGAl gene were 8, 100, and 88 for TT, TC, CC genotypes, respectively. The frequency of the T allele was 0.296 and $C$ allele was 0.704 . Finally, the genotype counts of the $M C 4 R$ gene were 125 , 59, and 11 for AA, AG, GG genotypes, respectively. The frequency of the $\mathrm{G}$ allele was 0.208 and A allele was 0.792 . Recently, many studies on gene markers associated with economic traits have been reported. Choi et al. (2012) studied a total of 81 SNP markers in the US commercial Duroc populations and found that 11 out of the 81 SNP markers were significantly associated with the carcass and meat quality traits of Duroc meat. Also, Rohrer et al. (2012) reported that PRKAG3, IGF2, CAST, and MC4R genes in commercial pigs have the greatest effects on the meat quality of pigs among the 45 candidate genes they have tested. On the other hand, according to the precedent studies, the frequency of PRKAG3 and MC4R genes from US Duroc pigs was similar with those of this study (Ciobanu et al., 2001; Davoli et al., 2012), However, we could not discover same FASN, CAST, and HMGAl genes with this study in other study.

\section{Relationship between five SNP genotypes and the carcass characteristics}

The associations of five SNP genotypes with the carcass characteristics of Duroc breeding stock are presented in Table 3. The carcass weight significantly was associated with $M C 4 R$ gene $(\mathrm{p}<0.0001)$. The pigs with $M C 4 R$ AA genotype had heavier carcass weight than those carrying $\mathrm{AG}$ and GG genotypes. Whereas, the PRKAG3, FASN, $C A S T$, and HMGAl genes did not show significant association with carcass weight. On the other hand, the pigs with AA genotype of FASN gene significantly were higher in backfat thickness than $\mathrm{CC}$ and $\mathrm{AC}$ genotype pigs. Also, the AA genotype of the CAST gene significantly increased the backfat thickness of pigs compared with AG and GG genotypes. The pigs with GG genotype of $M C 4 R$ gene were lower in the backfat thickness than GA and AA genotype pigs significantly $(\mathrm{p}<0.0001)$. However, there were no significant associations between the PRKAG3 and HMGAI genes and backfat thickness.

Kim et al. (2005) reported that the $M C 4 R$ NN genotypes of Duroc breed increased daily gain, feed conversion, backfat thickness and meat yield. Similar results were

Table 3. Association of SNP genotypes and their harboring genes with carcass traits in Duroc breeding stock

\begin{tabular}{|c|c|c|c|c|c|c|}
\hline \multirow{2}{*}{ Traits } & \multirow{2}{*}{ Genes $^{1}$} & \multirow{2}{*}{ p-value ${ }^{2}$} & \multirow{2}{*}{$\begin{array}{c}\text { SNP alleles } \\
\text { (minor/major) }\end{array}$} & \multicolumn{3}{|c|}{ Genotype average and standard errors ${ }^{3}$} \\
\hline & & & & DD & $\mathrm{Dd}$ & dd \\
\hline \multirow[t]{5}{*}{ Carcass weight (kg) } & PRKAG3 & 0.03 & $\mathrm{~A} / \mathrm{G}$ & $92.00 \pm 13.98$ & $89.15 \pm 8.62$ & $86.73 \pm 7.95$ \\
\hline & FASN & 0.87 & $\mathrm{C} / \mathrm{A}$ & $85.16 \pm 9.73$ & $88.90 \pm 9.50$ & $87.42 \pm 7.02$ \\
\hline & CAST & 0.01 & $\mathrm{~A} / \mathrm{G}$ & $90.13 \pm 6.51$ & $88.48 \pm 9.21$ & $86.23 \pm 7.96$ \\
\hline & $H M G A 1$ & 0.15 & $\mathrm{~T} / \mathrm{C}$ & $83.38 \pm 5.07$ & $89.75 \pm 9.08$ & $86.47 \pm 7.45$ \\
\hline & $M C 4 R$ & $* *$ & G/A & $79.50 \pm 9.48^{\mathrm{b}}$ & $84.97 \pm 7.77^{\mathrm{ab}}$ & $89.46 \pm 8.28^{\mathrm{a}}$ \\
\hline \multirow[t]{5}{*}{ Backfat thickness (mm) } & PRKAG3 & 0.41 & $\mathrm{~A} / \mathrm{G}$ & $22.50 \pm 2.50$ & $22.95 \pm 4.46$ & $22.31 \pm 5.12$ \\
\hline & FASN & $* * *$ & $\mathrm{C} / \mathrm{A}$ & $18.68 \pm 4.70^{\mathrm{c}}$ & $21.35 \pm 5.17^{\mathrm{b}}$ & $24.22 \pm 3.72^{\mathrm{a}}$ \\
\hline & CAST & $*$ & $\mathrm{~A} / \mathrm{G}$ & $25.19 \pm 3.81^{\mathrm{a}}$ & $22.72 \pm 4.45^{\mathrm{b}}$ & $21.36 \pm 5.10^{\mathrm{b}}$ \\
\hline & $H M G A 1$ & 0.06 & $\mathrm{~T} / \mathrm{C}$ & $21.00 \pm 5.26$ & $22.09 \pm 4.72$ & $23.25 \pm 4.82$ \\
\hline & $M C 4 R$ & $* *$ & G/A & $17.00 \pm 3.87^{\mathrm{b}}$ & $21.07 \pm 5.07^{\mathrm{a}}$ & $23.44 \pm 4.52^{\mathrm{a}}$ \\
\hline
\end{tabular}

SNP, single nucleotide polymorphism.

${ }^{1}$ PRKAG3, protein kinase adenosine monophosphate-activated $\gamma 3$ subunit; FASN, fatty acid synthase; CAST, calpastatin; HMGA1, high mobility group AT-hook 1; $M C 4 R$, melanocortin-4 receptor.

${ }^{2}$ Significant when $p$-values are $<0.003 .{ }^{3}$ Minor allele, "D"; Major allele, "d".

$* \mathrm{p}<0.003, * * \mathrm{p}<0.0001, * * * \mathrm{p}<0.00001$.

${ }^{\mathrm{a}-\mathrm{b}}$ Means with different superscription within the same raw differ $(\mathrm{p}<0.05)$. 
observed in another study using an Italian Duroc breed (Davoli et al., 2012). Previous studies have reported that the FASN gene was involved in the synthesis of fatty acids (Kim et al., 2011; Maharani et al., 2011). In this study, the AA genotype of the FSAN gene increased the backfat thickness of Duroc breed. The research of Kurył et al. (2003) and Krzęcio et al. (2008) demonstrated the effect of CAST gene on the increase or decrease of backfat thickness in various pig breeds.

\section{Relationship between five SNP genotypes and chemical composition}

The associations of five SNP genotypes with the chemical composition of LD muscle in Duroc breeding stock are described in Table 4. In the moisture content, the $M C 4 R$ gene showed significant impact, whereas the PRKAG3, FASN, CAST, and HMGAl genes were not associated with moisture content of LD muscle significantly. The GG genotype of $M C 4 R$ gene increased moisture content, whereas AA genotype lowered moisture content in LD muscle of Duroc population. Of the five genes, the FASN gene only was associated with intramuscular fat of LD muscle significantly. Meats from pigs with the AA genotype of FASN gene had significantly higher intramuscular fat than the $\mathrm{CC}$ genotype.

Ovilo et al. (2006) reported that the $M C 4 R$ gene was not associated with moisture, protein and intramuscular fat content of LD muscle in commercial pigs. On the other hand, Kim et al. (2006a) indicated that the MC4R genotypes affected lean meat growth in Duroc pigs. The moisture content of meat had a negative correlation with intramuscular fat content (Chin et al., 2012). Thus, an increase in leanness resulted in a decrease in fat content. Kim et al. (2011) reported that intramuscular fat content was associated with the FASN gene from the native Korean pigs crossed with Yorkshire or Landlace breeds. The relationship between the FASN gene and fat content in this study agreed with the tendency of native Korean pigs.

\section{Relationship between five SNP genotypes and meat quality}

The associations of five SNP genotypes with meat quality characteristics from LD muscle of Duroc breeding stock are shown in Table 5. The PRKAG3 gene significantly influenced on the $\mathrm{pH}_{24 \mathrm{~h}}$ of LD muscle from Duroc pigs $(\mathrm{p}<0.003)$. The AA genotype of pig showed a higher $\mathrm{pH}_{24 \mathrm{~h}}$ than those of GG genotype pig $(\mathrm{p}<0.05)$. In the shear force, the CAST gene had significant effect on the shear force of LD muscle of Duroc population. The pigs with AA genotype of the CAST gene had significantly lower shear force value than those with GG genotype pigs. The PRKAG3 gene also influenced on the redness and texture of LD muscle from Duroc pigs. The AA genotype of PRKAG3 gene significantly increased the redness of LD muscle compared with AG and GG genotypes, as well as the LD muscle containing the AA genotype of PRKAG3 gene showed more desirable texture score than GG genotype LD muscle $(\mathrm{p}<0.003)$. In addition, the FASN gene also affected the texture score of LD muscle significantly, and the texture score of muscle containing A allele was significantly higher than those of CC genotype.

The associations between meat quality and the PRKAG3 gene that regulates the glycogen content of intramuscular tissue are well established (Ciobanu et al., 2001). Furthermore, meat quality was influenced considerably by PRKAG3 genotypes. In post-mortem meat, the intramuscular glycogen content determines the $\mathrm{pH}$ of the meat through the glycolysis process. The ultimate $\mathrm{pH}$ of a

Table 4. Association of SNP genotypes and their harboring genes with chemical composition of LD muscle in Duroc breeding stock

\begin{tabular}{|c|c|c|c|c|c|c|}
\hline \multirow{2}{*}{ Traits } & \multirow{2}{*}{ Genes $^{1}$} & \multirow{2}{*}{ p-value ${ }^{2}$} & \multirow{2}{*}{$\begin{array}{c}\text { SNP alleles } \\
\text { (minor/major) }\end{array}$} & \multicolumn{3}{|c|}{ Genotype average and standard errors ${ }^{3}$} \\
\hline & & & & DD & Dd & dd \\
\hline \multirow[t]{5}{*}{ Moisture (\%) } & PRKAG3 & 0.66 & $\mathrm{~A} / \mathrm{G}$ & $73.24 \pm 0.49$ & $73.05 \pm 1.03$ & $73.14 \pm 1.07$ \\
\hline & FASN & 0.57 & $\mathrm{C} / \mathrm{A}$ & $73.33 \pm 0.91$ & $73.05 \pm 1.12$ & $73.08 \pm 1.04$ \\
\hline & CAST & 0.23 & $\mathrm{~A} / \mathrm{G}$ & $72.88 \pm 1.12$ & $73.11 \pm 0.95$ & $73.17 \pm 1.14$ \\
\hline & $H M G A 1$ & 0.43 & $\mathrm{~T} / \mathrm{C}$ & $73.45 \pm 1.28$ & $73.08 \pm 1.11$ & $73.03 \pm 0.97$ \\
\hline & $M C 4 R$ & $* *$ & $\mathrm{G} / \mathrm{A}$ & $74.32 \pm 0.22^{\mathrm{a}}$ & $73.45 \pm 0.89^{b}$ & $72.91 \pm 1.06^{\mathrm{b}}$ \\
\hline \multirow[t]{5}{*}{ Intramuscular fat $(\%)$} & PRKAG3 & 0.75 & $\mathrm{~A} / \mathrm{G}$ & $2.97 \pm 0.17$ & $2.99 \pm 0.93$ & $3.03 \pm 1.01$ \\
\hline & FASN & * & $\mathrm{C} / \mathrm{A}$ & $2.92 \pm 0.89^{\mathrm{b}}$ & $3.05 \pm 1.04^{\mathrm{a}}$ & $3.08 \pm 0.91^{\mathrm{a}}$ \\
\hline & $C A S T$ & 0.39 & $\mathrm{~A} / \mathrm{G}$ & $3.20 \pm 1.26$ & $2.94 \pm 0.89$ & $2.97 \pm 0.91$ \\
\hline & $H M G A 1$ & 0.70 & $\mathrm{~T} / \mathrm{C}$ & $3.01 \pm 0.57$ & $3.03 \pm 1.02$ & $2.97 \pm 0.92$ \\
\hline & $M C 4 R$ & 0.01 & G/A & $2.29 \pm 0.59$ & $2.76 \pm 0.76$ & $3.06 \pm 0.98$ \\
\hline
\end{tabular}

SNP, single nucleotide polymorphism; LD, longissimus dorsi.

${ }^{1}$ PRKAG3, protein kinase adenosine monophosphate-activated $\gamma 3$ subunit; FASN, fatty acid synthase; CAST, calpastatin; HMGA1, high mobility group AT-hook $1 ; M C 4 R$, melanocortin-4 receptor.

${ }^{2}$ Significant when $p$-values are $<0.003$. ${ }^{3}$ Minor allele, "D"; Major allele, "d".

$* \mathrm{p}<0.003, * * \mathrm{p}<0.0001, * * * \mathrm{p}<0.00001$.

${ }^{\mathrm{a}-\mathrm{b}}$ Means with different superscription within the same raw differ $(\mathrm{p}<0.05)$. 
Table 5. Association of SNP genotypes and their harboring genes with meat quality traits of LD muscle in Duroc breeding stock

\begin{tabular}{|c|c|c|c|c|c|c|}
\hline \multirow{2}{*}{ Traits } & \multirow{2}{*}{ Genes $^{1}$} & \multirow{2}{*}{$p$-value ${ }^{2}$} & \multirow{2}{*}{$\begin{array}{c}\text { SNP alleles } \\
\text { (minor/major) }\end{array}$} & \multicolumn{3}{|c|}{ Genotype average and standard errors ${ }^{3}$} \\
\hline & & & & DD & $\mathrm{Dd}$ & $\mathrm{dd}$ \\
\hline \multirow[t]{5}{*}{$\mathrm{pH}_{24 \mathrm{~h}}$} & PRKAG3 & $*$ & $\mathrm{~A} / \mathrm{G}$ & $5.85 \pm 0.10^{\mathrm{a}}$ & $5.77 \pm 0.17^{\mathrm{ab}}$ & $5.70 \pm 0.13^{\mathrm{b}}$ \\
\hline & FASN & 0.07 & $\mathrm{C} / \mathrm{A}$ & $5.79 \pm 0.21$ & $5.74 \pm 0.16$ & $5.72 \pm 0.13$ \\
\hline & CAST & 0.29 & $\mathrm{~A} / \mathrm{G}$ & $5.70 \pm 0.11$ & $5.77 \pm 0.17$ & $5.70 \pm 0.13$ \\
\hline & $H M G A 1$ & 0.19 & $\mathrm{~T} / \mathrm{C}$ & $5.71 \pm 0.14$ & $5.75 \pm 0.15$ & $5.71 \pm 0.15$ \\
\hline & $M C 4 R$ & 0.43 & $\mathrm{G} / \mathrm{A}$ & $5.80 \pm 0.13$ & $5.73 \pm 0.13$ & $5.73 \pm 0.15$ \\
\hline \multirow[t]{5}{*}{ Shear force $(\mathrm{kg})$} & PRKAG3 & 0.81 & $\mathrm{~A} / \mathrm{G}$ & $1.47 \pm 0.11$ & $1.49 \pm 0.27$ & $1.48 \pm 0.36$ \\
\hline & FASN & 0.01 & $\mathrm{C} / \mathrm{A}$ & $1.40 \pm 0.36$ & $1.44 \pm 0.33$ & $1.55 \pm 0.31$ \\
\hline & CAST & $*$ & $\mathrm{~A} / \mathrm{G}$ & $1.41 \pm 0.32^{\mathrm{b}}$ & $1.53 \pm 0.34^{\mathrm{ab}}$ & $1.60 \pm 0.29^{a}$ \\
\hline & $H M G A 1$ & 0.22 & $\mathrm{~T} / \mathrm{C}$ & $1.30 \pm 0.20$ & $1.50 \pm 0.33$ & $1.52 \pm 0.33$ \\
\hline & $M C 4 R$ & 0.05 & G/A & $1.43 \pm 0.27$ & $1.43 \pm 0.33$ & $1.52 \pm 0.32$ \\
\hline \multirow[t]{5}{*}{ Redness } & PRKAG3 & $* *$ & $\mathrm{~A} / \mathrm{G}$ & $5.12 \pm 0.86^{\mathrm{a}}$ & $4.52 \pm 0.92^{b}$ & $4.52 \pm 1.00^{\mathrm{b}}$ \\
\hline & FASN & 0.01 & $\mathrm{C} / \mathrm{A}$ & $5.47 \pm 1.11$ & $4.90 \pm 1.04$ & $4.70 \pm 0.89$ \\
\hline & $C A S T$ & 0.35 & $\mathrm{~A} / \mathrm{G}$ & $4.97 \pm 0.81$ & $4.67 \pm 1.03$ & $5.01 \pm 1.00$ \\
\hline & $H M G A 1$ & 0.89 & $\mathrm{~T} / \mathrm{C}$ & $5.50 \pm 1.00$ & $4.75 \pm 0.85$ & $4.94 \pm 1.15$ \\
\hline & $M C 4 R$ & 0.19 & G/A & $5.68 \pm 1.36$ & $4.87 \pm 1.08$ & $4.83 \pm 0.92$ \\
\hline \multirow[t]{5}{*}{ Texture $^{4}$} & PRKAG3 & $*$ & $\mathrm{~A} / \mathrm{G}$ & $3.38 \pm 0.29^{\mathrm{a}}$ & $3.15 \pm 0.30^{\mathrm{ab}}$ & $3.02 \pm 0.28^{\mathrm{b}}$ \\
\hline & FASN & $*$ & $\mathrm{C} / \mathrm{A}$ & $2.90 \pm 0.23^{\mathrm{b}}$ & $3.05 \pm 0.32^{\mathrm{a}}$ & $3.13 \pm 0.28^{a}$ \\
\hline & $C A S T$ & 0.75 & $\mathrm{~A} / \mathrm{G}$ & $3.05 \pm 0.22$ & $3.08 \pm 0.32$ & $3.07 \pm 0.31$ \\
\hline & $H M G A 1$ & 0.38 & $\mathrm{~T} / \mathrm{C}$ & $3.06 \pm 0.34$ & $3.05 \pm 0.32$ & $3.10 \pm 0.28$ \\
\hline & $M C 4 R$ & 0.51 & G/A & $3.03 \pm 0.20$ & $3.05 \pm 0.29$ & $3.08 \pm 0.31$ \\
\hline
\end{tabular}

SNP, single nucleotide polymorphism; LD, longissimus dorsi.

${ }^{1}$ PRKAG3, protein kinase adenosine monophosphate-activated $\gamma 3$ subunit; FASN, fatty acid synthase; CAST, calpastatin; HMGA1, high mobility group AT-hook 1; $M C 4 R$, melanocortin-4 receptor.

${ }^{2}$ Significant when $p$-values are $<0.003 .{ }^{3}$ Minor allele, "D"; Major allele, "d". ${ }^{4}$ Texture score: 1 , extremely undesirable; 5 , highly desirable.

$* \mathrm{p}<0.003, * * \mathrm{p}<0.0001, * * * \mathrm{p}<0.00001$.

${ }^{a-b}$ Means with different superscription within the same raw differ $(\mathrm{p}<0.05)$.

meat is an important indicator to evaluate meat quality (Park et al., 2002). Ciobanu et al. (2004) reported that CAST genotypes significantly affected the shear force, cooking loss, and juiciness values of pork from Berkshirex Yorkshire crossbred. However, in the present study, the CAST gene showed a significant association only with the shear force value of Duroc LD muscles. Significant association between PRKAG3 gene and redness was also revealed in the LD muscle of Duroc population. The meats from pigs with AA genotype showed a higher redness value than those with $\mathrm{AG}$ and $\mathrm{GG}$ genotypes. However, no significant associations between the meat quality parameters and rest of the genes tested were found.

The color of pork is largely determined by the $\mathrm{pH}$ of meat. Since the $\mathrm{pH}$ near the isoelectric point of muscle is caused by the accumulation of lactic acid, the moisture content of muscle is not preserved due to the weak ionic strength of myofibril (Park et al., 2002). Meat texture was closely associated with the PRKAG3 and FASN genes. The meat from pigs with AA genotype of the PRKAG3 gene showed a higher texture score than the $A G$ and $G G$ genotypes. The AA genotype of the FASN gene earned a higher score compared to that of the $\mathrm{AC}$ and $\mathrm{CC}$ genotypes. Texture score is evaluated by the firmness and springiness of meat surface. The PRKAG3 gene is highly correlated with the $\mathrm{pH}$ of meat (Milan et al., 2000; Ciobanu et al., 2001). The $\mathrm{pH}$ of meat is an indicator for determining normal, dark firm dry (DFD) or pale soft exudative (PSE) meat. Therefore, the PRKAG3 gene is significantly associated with the texture of meat. Furthermore, the FASN gene is known to be involved in the saturated/unsaturated ratio of fatty acids (Clop et al., 2003; Muñoz et al., 2007). Due to the differences in melting points of saturated and unsaturated fatty acids and the chain length of fatty acids, the fatty acid composition affects the texture of meat (Wood et al., 2004).

Relationship between five SNP genotypes and fatty acids

The associations of five SNP genotypes with fatty acids of Duroc breeding stock population are reported in Table 6 . The FASN, CAST, and MC4R genes showed significant effects on the fatty acids of LD muscle of Duroc population. The FASN and CAST genes had significant effects in increasing or decreasing palmitoleic acid (C16:1n7), stearic acid (C18:0) and oleic acid (C18:1n9) content of meat. Furthermore, the meats from pigs that carry AA genotype of the FASN gene showed significantly lower arachidonic acid (C20:4n6), but higher linoleic acid (C18:2n6), linolenic acid 
Table 6. i) Association of SNP genotypes and their harboring genes with fatty acids (\%) of LD muscle in Duroc breeding stock

\begin{tabular}{|c|c|c|c|c|c|c|}
\hline \multirow{2}{*}{ Traits } & \multirow{2}{*}{ Genes $^{1}$} & \multirow{2}{*}{ p-value ${ }^{2}$} & \multirow{2}{*}{$\begin{array}{l}\text { SNP alleles } \\
\text { (minor/major) }\end{array}$} & \multicolumn{3}{|c|}{ Genotype average and standard errors ${ }^{3}$} \\
\hline & & & & DD & $\mathrm{Dd}$ & dd \\
\hline \multirow[t]{5}{*}{ C16:0 } & PRKAG3 & 0.72 & $\mathrm{~A} / \mathrm{G}$ & $24.78 \pm 1.06$ & $25.29 \pm 1.00$ & $25.28 \pm 0.90$ \\
\hline & FASN & 0.28 & $\mathrm{C} / \mathrm{A}$ & $25.27 \pm 0.88$ & $25.43 \pm 0.98$ & $25.20 \pm 0.96$ \\
\hline & $C A S T$ & 0.20 & $\mathrm{~A} / \mathrm{G}$ & $25.47 \pm 0.85$ & $25.32 \pm 1.08$ & $25.21 \pm 0.87$ \\
\hline & $H M G A 1$ & 0.01 & $\mathrm{~T} / \mathrm{C}$ & $24.97 \pm 0.79$ & $25.16 \pm 0.91$ & $25.48 \pm 1.01$ \\
\hline & $M C 4 R$ & $* *$ & $\mathrm{G} / \mathrm{A}$ & $24.91 \pm 0.46^{\mathrm{b}}$ & $24.83 \pm 0.80^{\mathrm{b}}$ & $25.46 \pm 0.97^{\mathrm{a}}$ \\
\hline \multirow[t]{5}{*}{$\mathrm{C} 16: \ln 7$} & PRKAG3 & 0.91 & $\mathrm{~A} / \mathrm{G}$ & $3.02 \pm 0.60$ & $2.84 \pm 0.47$ & $2.87 \pm 0.48$ \\
\hline & $F A S N$ & $* *$ & $\mathrm{C} / \mathrm{A}$ & $3.15 \pm 0.39^{\mathrm{a}}$ & $2.97 \pm 0.48^{\mathrm{a}}$ & $2.73 \pm 0.43^{\mathrm{b}}$ \\
\hline & CAST & $*$ & $\mathrm{~A} / \mathrm{G}$ & $2.65 \pm 0.48^{b}$ & $2.83 \pm 0.46^{\mathrm{ab}}$ & $2.97 \pm 0.45^{\mathrm{a}}$ \\
\hline & $H M G A 1$ & 0.85 & $\mathrm{~T} / \mathrm{C}$ & $2.98 \pm 0.44$ & $2.84 \pm 0.49$ & $2.86 \pm 0.45$ \\
\hline & $M C 4 R$ & 0.01 & $\mathrm{G} / \mathrm{A}$ & $3.22 \pm 0.27$ & $2.97 \pm 0.48$ & $2.80 \pm 0.46$ \\
\hline \multirow[t]{5}{*}{ C18:0 } & PRKAG3 & 0.91 & $\mathrm{~A} / \mathrm{G}$ & $14.47 \pm 1.92$ & $14.70 \pm 1.29$ & $14.70 \pm 1.38$ \\
\hline & $F A S N$ & $* *$ & $\mathrm{C} / \mathrm{A}$ & $13.88 \pm 1.35^{\mathrm{b}}$ & $14.73 \pm 1.54^{\mathrm{a}}$ & $14.86 \pm 1.16^{\mathrm{a}}$ \\
\hline & CAST & $*$ & $\mathrm{~A} / \mathrm{G}$ & $15.03 \pm 1.58^{\mathrm{a}}$ & $14.84 \pm 1.32^{\mathrm{b}}$ & $14.47 \pm 1.28^{\mathrm{b}}$ \\
\hline & $H M G A 1$ & 0.85 & $\mathrm{~T} / \mathrm{C}$ & $14.68 \pm 1.34$ & $14.58 \pm 1.26$ & $14.91 \pm 1.45$ \\
\hline & $M C 4 R$ & 0.01 & $\mathrm{G} / \mathrm{A}$ & $13.39 \pm 1.36$ & $14.37 \pm 1.24$ & $14.88 \pm 1.35$ \\
\hline \multirow[t]{5}{*}{$\mathrm{C} 18: \ln 9$} & PRKAG3 & 0.81 & $\mathrm{~A} / \mathrm{G}$ & $42.26 \pm 2.86$ & $41.52 \pm 2.10$ & $41.68 \pm 2.06$ \\
\hline & $F A S N$ & $* * *$ & $\mathrm{C} / \mathrm{A}$ & $40.90 \pm 1.77^{b}$ & $42.21 \pm 2.11^{\mathrm{a}}$ & $42.96 \pm 1.81^{\mathrm{a}}$ \\
\hline & CAST & $*$ & $\mathrm{~A} / \mathrm{G}$ & $40.47 \pm 1.62^{b}$ & $41.57 \pm 2.10^{\mathrm{a}}$ & $42.10 \pm 2.02^{\mathrm{a}}$ \\
\hline & $H M G A 1$ & 0.01 & $\mathrm{~T} / \mathrm{C}$ & $42.34 \pm 2.70$ & $41.90 \pm 2.00$ & $41.17 \pm 2.00$ \\
\hline & $M C 4 R$ & 0.09 & G/A & $42.13 \pm 0.39$ & $42.02 \pm 2.22$ & $41.46 \pm 2.04$ \\
\hline \multirow[t]{5}{*}{$\mathrm{C} 18: 1 \mathrm{n} 7$} & PRKAG3 & 0.85 & $\mathrm{~A} / \mathrm{G}$ & $2.97 \pm 0.49$ & $2.78 \pm 0.44$ & $2.79 \pm 0.48$ \\
\hline & $F A S N$ & $* * *$ & $\mathrm{C} / \mathrm{A}$ & $2.63 \pm 0.45^{\mathrm{c}}$ & $2.90 \pm 0.44^{\mathrm{b}}$ & $3.13 \pm 0.43^{\mathrm{a}}$ \\
\hline & CAST & $*$ & $\mathrm{~A} / \mathrm{G}$ & $2.56 \pm 0.48^{\mathrm{b}}$ & $2.76 \pm 0.45^{\mathrm{a}}$ & $2.90 \pm 0.44^{\mathrm{a}}$ \\
\hline & $H M G A 1$ & 0.30 & $\mathrm{~T} / \mathrm{C}$ & $2.95 \pm 0.48$ & $2.79 \pm 0.49$ & $2.75 \pm 0.44$ \\
\hline & $M C 4 R$ & $* * *$ & G/A & $3.47 \pm 0.29^{\mathrm{a}}$ & $2.98 \pm 0.46^{\mathrm{b}}$ & $2.68 \pm 0.42^{\mathrm{b}}$ \\
\hline \multirow[t]{5}{*}{ C18:2n6 } & PRKAG3 & 0.67 & $\mathrm{~A} / \mathrm{G}$ & $9.32 \pm 2.38$ & $9.66 \pm 2.38$ & $9.46 \pm 2.26$ \\
\hline & FASN & $* * *$ & $\mathrm{C} / \mathrm{A}$ & $8.27 \pm 1.55^{\mathrm{b}}$ & $8.56 \pm 1.77^{\mathrm{b}}$ & $10.47 \pm 2.41^{\mathrm{a}}$ \\
\hline & CAST & 0.01 & $\mathrm{~A} / \mathrm{G}$ & $10.59 \pm 1.73$ & $9.50 \pm 2.39$ & $9.09 \pm 2.31$ \\
\hline & $H M G A 1$ & 0.50 & $\mathrm{~T} / \mathrm{C}$ & $8.75 \pm 2.59$ & $9.54 \pm 2.27$ & $9.61 \pm 2.37$ \\
\hline & $M C 4 R$ & 0.70 & G/A & $9.07 \pm 1.19$ & $9.51 \pm 2.55$ & $9.57 \pm 2.29$ \\
\hline \multirow[t]{5}{*}{ C18:3n6 } & $P R K A G 3$ & 0.22 & $\mathrm{~A} / \mathrm{G}$ & $0.05 \pm 0.01$ & $0.05 \pm 0.01$ & $0.05 \pm 0.01$ \\
\hline & $F A S N$ & 0.57 & $\mathrm{C} / \mathrm{A}$ & $0.05 \pm 0.01$ & $0.05 \pm 0.01$ & $0.05 \pm 0.01$ \\
\hline & $C A S T$ & 0.28 & $\mathrm{~A} / \mathrm{G}$ & $0.05 \pm 0.00$ & $0.05 \pm 0.01$ & $0.05 \pm 0.01$ \\
\hline & $H M G A 1$ & 0.12 & $\mathrm{~T} / \mathrm{C}$ & $0.05 \pm 0.00$ & $0.05 \pm 0.01$ & $0.05 \pm 0.01$ \\
\hline & $M C 4 R$ & $*$ & G/A & $0.06 \pm 0.01^{\mathrm{a}}$ & $0.05 \pm 0.01^{\mathrm{ab}}$ & $0.05 \pm 0.01^{\mathrm{b}}$ \\
\hline \multirow[t]{5}{*}{ C18:3n3 } & PRKAG3 & 0.54 & $\mathrm{~A} / \mathrm{G}$ & $0.38 \pm 0.08$ & $0.43 \pm 0.11$ & $0.42 \pm 0.11$ \\
\hline & FASN & $* * *$ & $\mathrm{C} / \mathrm{A}$ & $0.37 \pm 0.10^{\mathrm{b}}$ & $0.38 \pm 0.10^{b}$ & $0.46 \pm 0.10^{\mathrm{a}}$ \\
\hline & $C A S T$ & 0.01 & $\mathrm{~A} / \mathrm{G}$ & $0.47 \pm 0.08$ & $0.43 \pm 0.10$ & $0.40 \pm 0.12$ \\
\hline & HMGAl & 0.66 & $\mathrm{~T} / \mathrm{C}$ & $0.41 \pm 0.16$ & $0.42 \pm 0.10$ & $0.43 \pm 0.11$ \\
\hline & $M C 4 R$ & 0.09 & $\mathrm{G} / \mathrm{A}$ & $0.30 \pm 0.05$ & $0.42 \pm 0.13$ & $0.43 \pm 0.10$ \\
\hline \multirow[t]{5}{*}{ C20:4n6 } & PRKAG3 & 0.21 & $\mathrm{~A} / \mathrm{G}$ & $0.42 \pm 0.04$ & $0.41 \pm 0.19$ & $0.46 \pm 0.27$ \\
\hline & $F A S N$ & $*$ & $\mathrm{C} / \mathrm{A}$ & $0.57 \pm 0.42^{\mathrm{a}}$ & $0.46 \pm 0.22^{b}$ & $0.39 \pm 0.18^{\mathrm{b}}$ \\
\hline & $C A S T$ & 0.01 & $\mathrm{~A} / \mathrm{G}$ & $0.38 \pm 0.22$ & $0.40 \pm 0.18$ & $0.50 \pm 0.27$ \\
\hline & $H M G A 1$ & 0.61 & $\mathrm{~T} / \mathrm{C}$ & $0.51 \pm 0.14$ & $0.41 \pm 0.20$ & $0.45 \pm 0.27$ \\
\hline & $M C 4 R$ & $* * *$ & G/A & $1.08 \pm 0.45^{\mathrm{a}}$ & $0.54 \pm 0.22^{b}$ & $0.37 \pm 0.17^{c}$ \\
\hline
\end{tabular}

(C18:3n3), and poly-unsaturated fatty acid content than CC genotype. The meats from pigs that carry AA genotype of the CAST gene showed significantly lower content of mono-unsaturated fatty acids than the $A G$ and $G G$ genotypes. Cameron and Enser (1991) reported that flavor quality traits were improved as the concentration of monounsaturated fatty acids increased and poly-unsaturated fatty acids decreased. Further, De Smet et al. (2004) indicated that the contents of saturated and mono-unsaturated fatty acids increased faster than those of poly-unsaturated fatty 
Table 6. ii) Association of SNP genotypes and their harboring genes with fatty acids (\%) of LD muscle in Duroc breeding stock

\begin{tabular}{|c|c|c|c|c|c|c|}
\hline \multirow{2}{*}{ Traits } & \multirow{2}{*}{ Genes $^{1}$} & \multirow{2}{*}{ p-value ${ }^{2}$} & \multirow{2}{*}{$\begin{array}{c}\text { SNP alleles } \\
\text { (minor/major) }\end{array}$} & \multicolumn{3}{|c|}{ Genotype average and standard errors ${ }^{3}$} \\
\hline & & & & DD & $\mathrm{Dd}$ & $\mathrm{dd}$ \\
\hline \multirow[t]{5}{*}{ SFA } & PRKAG3 & 0.83 & $\mathrm{~A} / \mathrm{G}$ & $40.72 \pm 2.50$ & $41.46 \pm 2.01$ & $41.43 \pm 1.97$ \\
\hline & FASN & 0.30 & C/A & $40.63 \pm 1.92$ & $41.62 \pm 2.25$ & $41.51 \pm 1.83$ \\
\hline & $C A S T$ & 0.04 & $\mathrm{~A} / \mathrm{G}$ & $41.96 \pm 2.07$ & $41.61 \pm 2.06$ & $41.14 \pm 1.93$ \\
\hline & $H M G A 1$ & 0.03 & $\mathrm{~T} / \mathrm{C}$ & $41.15 \pm 2.06$ & $41.18 \pm 1.76$ & $41.85 \pm 2.22$ \\
\hline & $M C 4 R$ & $* *$ & G/A & $39.83 \pm 1.47^{b}$ & $40.66 \pm 1.67^{\mathrm{ab}}$ & $41.79 \pm 2.05^{\mathrm{a}}$ \\
\hline \multirow[t]{5}{*}{ USFA } & PRKAG3 & 0.83 & $\mathrm{~A} / \mathrm{G}$ & $59.28 \pm 2.50$ & $58.54 \pm 2.01$ & $58.57 \pm 1.97$ \\
\hline & FASN & 0.30 & $\mathrm{C} / \mathrm{A}$ & $59.37 \pm 1.92$ & $58.38 \pm 2.25$ & $58.49 \pm 1.83$ \\
\hline & $C A S T$ & 0.04 & $\mathrm{~A} / \mathrm{G}$ & $58.04 \pm 2.07$ & $58.39 \pm 2.06$ & $58.86 \pm 1.93$ \\
\hline & $H M G A 1$ & 0.03 & $\mathrm{~T} / \mathrm{C}$ & $58.85 \pm 2.06$ & $58.82 \pm 1.76$ & $58.15 \pm 2.22$ \\
\hline & $M C 4 R$ & $* *$ & $\mathrm{G} / \mathrm{A}$ & $60.17 \pm 1.47^{a}$ & $59.34 \pm 1.67^{\mathrm{ab}}$ & $58.21 \pm 2.05^{\mathrm{b}}$ \\
\hline \multirow[t]{5}{*}{ Mono-USFA } & PRKAG3 & 0.89 & $\mathrm{~A} / \mathrm{G}$ & $49.11 \pm 3.93$ & $47.99 \pm 2.71$ & $48.19 \pm 2.73$ \\
\hline & $F A S N$ & $* * *$ & $\mathrm{C} / \mathrm{A}$ & $50.11 \pm 2.36$ & $48.93 \pm 2.75$ & $47.11 \pm 2.33$ \\
\hline & $C A S T$ & $*$ & $\mathrm{~A} / \mathrm{G}$ & $46.55 \pm 2.36^{b}$ & $48.01 \pm 2.75^{\mathrm{a}}$ & $48.82 \pm 2.57^{\mathrm{a}}$ \\
\hline & $H M G A 1$ & 0.02 & $\mathrm{~T} / \mathrm{C}$ & $49.13 \pm 3.46$ & $48.40 \pm 2.73$ & $47.61 \pm 2.60$ \\
\hline & $M C 4 R$ & 0.01 & $\mathrm{G} / \mathrm{A}$ & $49.65 \pm 0.49$ & $48.82 \pm 2.96$ & $47.79 \pm 2.63$ \\
\hline \multirow[t]{5}{*}{ Poly-USFA } & PRKAG3 & 0.74 & $\mathrm{~A} / \mathrm{G}$ & $10.17 \pm 2.44$ & $10.55 \pm 2.45$ & $10.38 \pm 2.33$ \\
\hline & $F A S N$ & $* * *$ & $\mathrm{C} / \mathrm{A}$ & $9.27 \pm 1.72^{\mathrm{b}}$ & $9.45 \pm 1.84^{\mathrm{b}}$ & $11.38 \pm 2.49^{\mathrm{a}}$ \\
\hline & $C A S T$ & 0.01 & $\mathrm{~A} / \mathrm{G}$ & $11.49 \pm 1.74$ & $10.38 \pm 2.44$ & $10.03 \pm 2.43$ \\
\hline & $H M G A 1$ & 0.47 & $\mathrm{~T} / \mathrm{C}$ & $9.72 \pm 2.68$ & $10.42 \pm 2.32$ & $10.53 \pm 2.45$ \\
\hline & $M C 4 R$ & 0.81 & $\mathrm{G} / \mathrm{A}$ & $10.52 \pm 1.60$ & $10.52 \pm 2.64$ & $10.42 \pm 2.34$ \\
\hline
\end{tabular}

SNP, single nucleotide polymorphism; LD, longissimus dorsi; SFA, saturated fatty acid; USFA, unsaturated fatty acid.

${ }^{1}$ PRKAG3, protein kinase adenosine monophosphate-activated $\gamma 3$ subunit; FASN, fatty acid synthase; CAST, calpastatin; HMGA1, high mobility group AT-hook 1; MC4R, melanocortin-4 receptor.

${ }^{2}$ Significant when $p$-values are $<0.003 .{ }^{3}$ Minor allele, "D"; Major allele, "d".

$* \mathrm{p}<0.003, * * \mathrm{p}<0.0001, * * * \mathrm{p}<0.00001$.

${ }^{\mathrm{a}-\mathrm{b}}$ Means with different superscription within the same raw $\operatorname{differ}(\mathrm{p}<0.05)$.

acids as the fatness increased. Although, the fatty acid composition of meat is influenced by genetic factors, their influence was lower than that of the dietary factors. The $M C 4 R$ gene was significantly associated palmitic acid (C16:0), oleic acid (C18:1n7), linolenic acid (C18:3n6), arachidonic acid (C20:4n6), total saturated fatty acid, and total unsaturated fatty acid contents of LD muscle. Our results agreed with those of Ovilo et al. (2006) who reported that the pigs with $M C 4 R$ AA genotype showed higher saturated fatty acids and lower unsaturated fatty acids content than the GG genotype pigs. Excessive unsaturated fatty acids (C18:2n6, C18:3n3, and C20:4n6) causes softening of meat and accelerates oxidative changes. Also, the concentration of saturated fatty acids is related to the hardness of meat (Wood et al., 2004; Bertol et al., 2013). However, the intake of saturated fatty acids in meat is recently becoming an issue due to increased health concerns about saturated fatty acids. So, the genes involved in fatty acid compositions of meat need further attentions.

\section{CONCLUSION}

All five SNP marker (PRKAG3, FASN, CAST, HMGAl, and $M C 4 R$ ) genes, except for $H M G A l$ were significantly associated with the meat quality traits of Duroc population. The PRKAG3 AA genotype increased $\mathrm{pH}_{24 \mathrm{~h}}$, redness, and texture values of pork LD muscle. The FASN gene AA genotype increased backfat thickness, texture values, stearic acid, oleic acid, and poly-unsaturated fatty acid content, whereas the CAST AA genotype increased backfat thickness, lowered shear force, palmitoleic acid, oleic acid, and increased stearic acid content in Duroc pork. The MC4R AA genotype increased backfat thickness, carcass weight, moisture, and saturated fatty acid, and decreased unsaturated fatty acid. Therefore, the genetic information from Duroc breeding stocks can be utilized effectively by swine industry to improve pork quality, and to meet the changing consumer demands. The grade evaluation standard of pork in Korea was revised in 2013 to enhance the meat quality by reducing the importance of backfat thickness and carcass weight. For quality grade, grading items for fat deposition, meat color, meat texture, fat color, and fat texture have also been changed (Guidelines of Livestock Products Sanitary Control Act, Ministry of Food and Drug Safety in Korea, 2014). Obviously, this study of genomic information related to carcass characteristics from each pig will be helpful in controlling the backfat thickness and carcass weight of pigs. Thus, the genotypes of gene can 
be used to determine the phenotypes of each individual pig, and this information can be applied to the breeding industry to improve pork quality in commercial pigs.

\section{CONFLICT OF INTEREST}

We certify that there is no conflict of interest with any financial organization regarding the material discussed in the manuscript.

\section{ACKNOWLEDGMENTS}

This research was supported by Korea Institute of Planning and Evaluation for Technology in Food, Agriculture, Forestry and Fisheries (IPET) through AgriBioindustry Technology Development Program funded by Ministry of Agriculture, Food and Rural Affairs (114073-3). This research was also supported by the Priority Research Centers Program through the National Research Foundation of Korea (NRF), funded by the Ministry of Education (2009-0093813).

\section{REFERENCES}

Adan, R. A. H., B. Tiesjema, J. J. G. Hillebrand, S. E. la Fleur, M. J. H. Kas, and M. de Krom. 2006. The MC4 receptor and control of appetite. Br. J. Pharmacol. 149:815-827.

Bertol, T. M., R. M. L. de Campos, J. V. Ludke, N. N. Terra, E. A. P. de Figueiredo, A. Coldebella, J. I. dos Santos Filho, V. L. Kawski, and N. M. Lehr. 2013. Effects of genotype and dietary oil supplementation on performance, carcass traits, pork quality and fatty acid composition of backfat and intramuscular fat. Meat Sci. 93:507-516.

Cameron, N. D. and M. B. Enser. 1991. Fatty acid composition of lipid in longissimus dorsi muscle of duroc and british landrace pigs and its relationship with eating quality. Meat Sci. 29:295307.

Chin, K. B., M. Y. Go, H. C. Lee, S. K. Chung, K. H. Baik, and C. B. Choi. 2012. Articles: Physicochemical properties and tenderness of hanwoo loin and round as affected by raising period and marbling score. Korean J. Food Sci. An. 32:842848.

Choi, I., R. O. Bates, N. E. Raney, J. P. Steibel, and C. W. Ernst. 2012. Evaluation of QTL for carcass merit and meat quality traits in a US commercial Duroc population. Meat Sci. 92:132138.

Ciobanu, D., J. Bastiaansen, M. Malek, J. Helm, J. Woollard, G. Plastow, and M. Rothschild. 2001. Evidence for new alleles in the protein kinase adenosine monophosphate-activated gamma(3)-subunit gene associated with low glycogen content in pig skeletal muscle and improved meat quality. Genetics 159:1151-1162.

Ciobanu, D. C., J. W. Bastiaansen, S. M. Lonergan, H. Thomsen, J. C. Dekkers, G. S. Plastow, and M. F. Rothschild. 2004. New alleles in calpastatin gene are associated with meat quality traits in pigs. J. Anim. Sci. 82:2829-2839.

Clop, A., C. Ovilo, M. Perez-Enciso, A. Cercos, A. Tomas, A. Fernandez, A. Coll, J. M. Folch, C. Barragan, I. Diaz, M. A. Oliver, L. Varona, L. Silio, A. Sanchez, and J. L. Noguera. 2003. Detection of qtl affecting fatty acid composition in the pig. Mamm. Genome 14:650-656.

Dalvit, C., M. De Marchi, and M. Cassandro. 2007. Genetic traceability of livestock products: A review. Meat Sci. 77:437449.

Davoli, R., S. Braglia, V. Valastro, C. Annarratone, M. Comella, P. Zambonelli, I. Nisi, M. Gallo, L. Buttazzoni, and V. Russo. 2012. Analysis of $M C 4 R$ polymorphism in italian large white and italian duroc pigs: Association with carcass traits. Meat sci. 90:887-892.

De Smet, S., K. Raes, and D. Demeyer. 2004. Meat fatty acid composition as affected by fatness and genetic factors: A review. Anim. Res. 53:81-98.

Folch, J., M. Lees, and G. Sloane-Stanley. 1957. A simple method for the isolation and purification of total lipides from animal tissues. J. Biol. Chem. 226:497-509.

Ibáñez-Escriche, N., S. Forni, J. L. Noguera, and L. Varona. 2014. Genomic information in pig breeding: Science meets industry needs. Livest. Sci. 166:94-100.

Jang, Y. J., M. R. Ji, M. H. Jeon, J. S. Kim, K. W. Kim, D. W. Han, H. J. Chung, B. C. Yang, J. G. Yoo, J. K. Park, T. O. Kim, and S. J. Byun. 2012. Analysis of the foreign gene transmission in the gfp transgenic chickens. Korean J. Poult. Sci. 39:241-244.

Kim, K. S., J. J. Lee, H. Y. Shin, B. H. Choi, C. K. Lee, J. J. Kim, B. W. Cho, and T. H. Kim. 2006a. Association of melanocortin 4 receptor $(M C 4 R)$ and high mobility group at-hook 1 (HMGA1) polymorphisms with pig growth and fat deposition traits. Anim. Genet. 37:419-421.

Kim, K. S., N. Larsen, T. Short, G. Plastow, and M. F. Rothschild. 2000. A missense variant of the porcine melanocortin-4 receptor $(M C 4 R)$ gene is associated with fatness, growth, and feed intake traits. Mamm. Genome. 11:131-135.

Kim, K. S., J. J. Lee, H. Y. Shin, B. H. Choi, C. K. Lee, J. J. Kim, B. W. Cho, and T. H. Kim. 2006b. Association of melanocortin 4 receptor $(M C 4 R)$ and high mobility group at-hook 1 (HMGA1) polymorphisms with pig growth and fat deposition traits. Anim. Genet. 37:419-421.

Kim, K. S., H. Y. Shin, J. J. Lee, S. K. Hong, B-H. Choi, T. H. Kim, H. K. Lee, and B. W. Cho. 2005. Investigation of porcine melanocortin-4 receptor $(M C 4 R)$ polymorphism on economic traits. J. Life Sci. 15:968-971.

Kim, K. S., H. Thomsen, J. Bastiaansen, N. T. Nguyen, J. C. Dekkers, G. S. Plastow, and M. F. Rothschild. 2004. Investigation of obesity candidate genes on porcine fat deposition quantitative trait loci regions. Obes. Res. 12:19811994.

Kim, S. W., Y. I. Choi, J. S. Choi, J. J. Kim, B. H. Choi, T. H. Kim, and K. S. Kim. 2011. Article: Porcine fatty acid synthase gene polymorphisms are associated with meat quality and fatty acid composition. Korean J. Food Sci. An. 31:356-365.

Krzęcio, E., M. Koćwin-Podsiadła, J. Kurył, A. Zybert, H. Sieczkowska, and K. Antosik. 2008. The effect of interaction between genotype CAST/RsaI (calpastatin) and MYOG/MspI 
(myogenin) on carcass and meat quality in pigs free of $R Y R I^{\mathrm{T}}$ allele. Meat Sci. 80:1106-1115.

Kurył, J., W. Kapelański, M. Pierzchała, S. Grajewska, and M. Bocian. 2003. Preliminary observations on the effect of calpastatin gene (CAST) polymorphism on carcass traits in pigs. Anim. Sci. Pap. Rep. 21:87-95.

Lonergan, E. H., W. Zhang, and S. M. Lonergan. 2010. Biochemistry of postmortem muscle-Lessons on mechanisms of meat tenderization. Meat Sci. 86:184-195.

Maharani, D., C. Jo, J. T. Jeon, and J. H. Lee. 2011. Review: Quantitative trait loci and candidate genes affecting fatty acid composition in cattle and pig. Korean J. Food Sci. An. 31:325338.

Mignon-Grasteau, S., A. Boissy, J. Bouix, J.-M. Faure, A. D. Fisher, G. N. Hinch, P. Jensen, P. Le Neindre, P. Mormède, and P. Prunet. 2005. Genetics of adaptation and domestication in livestock. Livest. Prod. Sci. 93:3-14.

Milan, D., J.-T. Jeon, C. Looft, V. Amarger, A. Robic, M. Thelander, C. Rogel-Gaillard, S. Paul, N. Iannuccelli, and L. Rask. 2000. A mutation in PRKAG3 associated with excess glycogen content in pig skeletal muscle. Science 288:12481251.

Ministry of Food and Drug Safety in Korea. 2010. Livestock Products Sanitary Control Act. No. 10310. Seoul, Korea.

Ministry of Food and Drug Safety in Korea. 2014. Livestock Products Sanitary Control Act. No. 12672. Seoul, Korea.

Morrison, W. R. and L. M. Smith. 1964. Preparation of fatty acid methyl esters and dimethylacetals from lipids with boron fluoride-methanol. J. Lipid Res. 5:600-608.
Muñoz, G., E. Alves, A. Fernandez, C. Ovilo, C. Barragan, J. Estelle, R. Quintanilla, J. Folch, L. Silio, and M. Rodriguez. 2007. QTL detection on porcine chromosome 12 for fatty-acid composition and association analyses of the fatty acid synthase, gastric inhibitory polypeptide and acetyl-coenzyme a carboxylase alpha genes. Anim. Genet. 38:639-646.

National Institute of Animal Science. 2012. Korean feeding standard for swine National Institute of Animal Science, NIAS, Suwon, Korea.

Ovilo, C., A. Fernández, M. C. Rodríguez, M. Nieto, and L. Silió. 2006. Association of $M C 4 R$ gene variants with growth, fatness, carcass composition and meat and fat quality traits in heavy pigs. Meat Sci. 73:42-47.

Park, B., S. Cho, Y. Yoo, J. Kim, H. Chae, J. Ahn, Y. Kim, J. Lee, and S. Yun. 2002. Comparison of pork quality by different postmortem pH24 values. Korean J. Anim. Sci. Technol. 44:233-238.

Rohrer, G., D. Nonneman, R. Miller, H. Zerby, and S. Moeller, 2012. Association of single nucleotide polymorphism (SNP) markers in candidate genes and qtl regions with pork quality traits in commercial pigs. Meat Sci. 92:511-518.

SAS, P. 2003. Windows version 9.1. 3. SAS Institute Inc., Cary, NC, USA.

Suzuki, K., T. Shibata, H. Kadowaki, H. Abe, and T. Toyoshima. 2003. Meat quality comparison of berkshire, duroc and crossbred pigs sired by berkshire and duroc. Meat Sci. 64:3542.

Wood, J., R. Richardson, G. Nute, A. Fisher, M. Campo, E. Kasapidou, P. Sheard, and M. Enser. 2004. Effects of fatty acids on meat quality: A review. Meat Sci. 66:21-32. 